\title{
Metode USLE untuk Memprediksi Erosi Tanah dan Nilai Toleransi Erosi Sebuah Sistem Agricultural di Desa Genengan Kecamatan Jumantono Karanganyar
}

\section{USLE Method for Prediction Soil Erosion and Tolerated Erosion Value an Agricultural Systems in Genengan Village District Jumantono Karanganyar}

\author{
Ari Widodo ${ }^{1)}$, Komariah ${ }^{2)}$, Jaka Suyana ${ }^{2)}$
}

\begin{abstract}
Erosion can potentially cause of land degradation. Prediction of erosion rate is needed on a certain plots of land so the sustainability of the farming system and appropriate conservation recommendations can be known. This research is intended to obtain information of erosivity value comparison in supporting erosion prediction acuracy USLE method to get erosion prediction value and erosion tolerated value (Etol). This information will be used to the determine the recommendations technology conservation on farming system of Genengan village, district Jumantono, Karanganyar Regency. A explorative descriptive research is using a land units map as the basic unit of analysis a survey in the field. The determination of sample unit is based on the land unit map from the overlay of land slope maps, land use maps, and soil maps on the land system Samin watershed. Results showed that the magnitude in Genengan Village on the land unit 1, land unit 2, land unit 5, land unit 6 and land unit 8 still under the tolerance value. Meanwhile land unit 3, land unit 4 and land unit 7 are exceeded the value this requires need for conservation. The suggested conservation is for the land unit 3 by planting 9 of vetiver between the main plant, where as on the land unit 4 and land unit 7 is recomended to apply $60 \%$ of straw mulch.
\end{abstract}

Keywords : erosivity value, conservation

\section{PENDAHULUAN}

Erosi adalah peristiwa pindahnya atau terangkutnya tanah atau bagian - bagian tanah dari suatu tempat ke tempat lain oleh media alami. Pada peristiwa erosi, tanah atau bagian - bagian tanah pada suatu tempat terkikis dan terangkut yang kemudian diendapkan di tempat lain. Pengikisan dan pengangkutan tanah tersebut terjadi oleh media alami yaitu air dan angin. Erosi oleh angin disebabkan oleh kekuatan angin, sedangkan erosi oleh air ditimbulkan oleh kekuatan air. Erosi sering terjadi di daerah beriklim basah, sedangkan erosi angin merupakan peristiwa yang terjadi di daerah beriklim kering, sedangkan Indonesia adalah daerah tropis yang umumnya beriklim basah atau agak basah (Arsyad 2010).

Desa Genengan merupakan salah satu desa di Kecamatan Jumantono, Kabupaten Karanganyar. Luas desa ini sekitar 703,23 Ha dengan sebagian besar penggunaan lahan adalah lahan pertanian terutama sawah tadah hujan dan tegalan. Secara astronomis desa ini berada pada $110^{\circ} 59^{\prime} 25^{\prime \prime}$ $110^{\circ} 02^{\prime} 5,2^{\prime \prime}$ BT dan 07 $39^{\prime} 23,8^{\prime \prime}-07^{\circ} 40^{\prime} 34,7^{\prime \prime}$ LS. Curah hujan cukup tinggi berkisar antara 1500-3500 $\mathrm{mm} /$ tahun dan berada pada ketinggian sekitar 550 meter di atas permukaan laut (m dpl). Berdasarkan hasil pengamatan lapang, Desa Genengan

1) Undergraduate Student of Study Program of Agrotechnology, Faculty of Agriculture University of Sebelas Maret (UNS) in Surakarta.

2) Lecturer of Study Program of Agrotechnology, Faculty of Agriculture University of Sebelas Maret (UNS) in Surakarta.

Contact Author: jokosuyonouns@yahoo.com mempunyai kemiringan bervariasi yaitu $<3 \%, 3-8 \%$, 8 $15 \%, 15-30 \%$ dan $>30 \%$. Ditinjau dari penggunaan lahan bervariasi seperti hutan rakyat, pemukiman, sawah dan tegal. Kondisi tersebut dan diperkuat adanya penelitian yang menunjukkan percepatan mineralisasi bahan organik di Kecamatan Jumantono, maka perlu diadakan pengukuran laju erosi. Adanya stasiun klimatologi di daerah tersebut memungkinkan untuk dapat dilakukan prediksi erosi dengan berbagai metode penghitungan nilai erosivitas.

Prediksi laju erosi dibutuhkan untuk mengetahui besarnya laju erosi di Desa Genengan, Kecamatan Jumantono. Setelah mendapat perkiraan angka laju erosi maka akan dapat ditentukan metode konservasi yang sesuai kondisi lahan dan sistem pertanian di wilayah tersebut. Pada penelitian ini mengkaji seberapa besar prediksi erosi yang terjadi pada sistem pertanian di Desa Genengan dengan metode USLE menggunakan nilai Erosivitas Lenvain 1975, Lenvain 1989 dan Bols. Setelah diketahui prediksi erosi, maka juga akan dievaluasi nilai erosi pada sistem pertanian di Desa Genengan yang masih dapat ditoleransikan sebagai acuan rekomendasi teknologi konservasi yang sesuai dan memadai pada sistem pertanian di Desa Genengan.

\section{METODE PENELITIAN}

Penelitian ini dilaksanakan pada bulan November 2013 hingga April 2014. Tempat penelitian di Desa Genengan Kecamatan Jumantono Kabupaten Karanganyar. Analisis sampel tanah dilakukan di Laboratorium Fisika Tanah dan Laboratorium Kimia dan Kesuburan Tanah Fakultas Pertanian, Universitas Sebelas Maret Surakarta. Bahan- bahan yang diperlukan dalam penelitian ini, diantaranya meliputi : 
peta Land Unit SUB DAS Samin, data curah hujan bulanan selama 10 tahun, data curah hujan harian selama 10 tahun dan bahan- bahan kimia untuk analisa di laboratorium.Peralatan yang digunakan selama penelitian dilakukan diantaranya adalah bor tanah, GPS, cangkul, pisau lapang, ring sampel, klinometer, meteran, peralatan tulis, peralatan untuk analisa dilaboratorium beserta unit komputer lengkap dengan software Ms Office 2010, ArcView, ArcGis dan Printer.

Penelitian ini merupakan penelitian survei dengan pendekatan satuan lahan sebagai unit dasar analisis survei di lapang untuk dianalisis dan diolah menjadi data deskriptif untuk menyatakan nilai prediksi erosi dan Etol. Variabel yang diamati di lapang meliputi panjang lereng, kemiringan lereng, pengelolaan tanaman, kedalaman jeluk dan tindakan konservasi. sedangkan variabel yang diukur di laboratorium meliputi tekstur, struktur, permeabilitas, berat volume, kapasitas lapang, dan bahan organik. Penentuan titik sampel berdasarkan peta satuan lahan dari hasil overlay peta kemiringan tanah, peta penggunaan lahan, dan peta jenis tanah pada sistem lahan Sub Das Samin. Pada titik-titik ini akan diambil sampel tanah dan diamati kondisi fisik lahan. Variabel yang akan diukur untuk prediksi erosi dilakukan berdasar metode USLE (Wischmeier \& Smith 1978). Penetapan besarnya nilai erosi yang masih dapat ditoleransikan nilai ETol digunakan untuk menentukan nilai ambang batas erosi menggunakan metode Wood dan Dent 1983.

\section{HASIL DAN PEMBAHASAN}

\section{Peta Satuan Lahan Desa Genengan}

Peta Satuan Lahan Desa Genengan merupakan hasil tumpang tindih peta jenis tanah, peta kemiringan lereng dan peta penggunaan lahan yang digunakan untuk menentukan jumlah dan lokasi pengambilan titik sampel. Kenampakan peta satuan lahan Desa Genengan akan disajikan pada Gambar 1.

\section{Prediksi Erosi Metode USLE dengan Berbagai Nilai Erosivitas pada Satuan Lahan di Desa Genengan Kecamatan Jumantono, Karanganyar}

Prediksi erosi pada lahan pertanian Desa Genengan dilakukan dengan mengambil sampel pada setiap unit lahan. Rumus yang dipakai adalah: A = R K L S C P ..............(1)

dimana :

$\mathrm{A}=$ Banyaknya tanah tererosi (ton/ ha/ tahun),

$\mathrm{R}=$ Erosivitas hujan $(\mathrm{cm})$,

$\mathrm{K}=$ Erodibilitas tanah,

$\mathrm{L}=$ Panjang lereng $(\mathrm{m})$.

$\mathrm{S}=$ Kemiringan lereng (\%).

$\mathrm{C}=$ Vegetasi penutup tanah dan pengelolaan tanaman

$\mathrm{P}=$ Faktor tindakan khusus konservasi tanah digunakan (Arsyad, 2010)

Setelah nilai R, K, LS dan CP tersedia, maka besarnya erosi dapat ditentukan menggunakan metode USLE. Berikut ini pada Tabel 1 akan ditampilkan hasil prediksi erosi metode USLE dengan berbagai pendekatan nilai Erosivitas atau $R$.

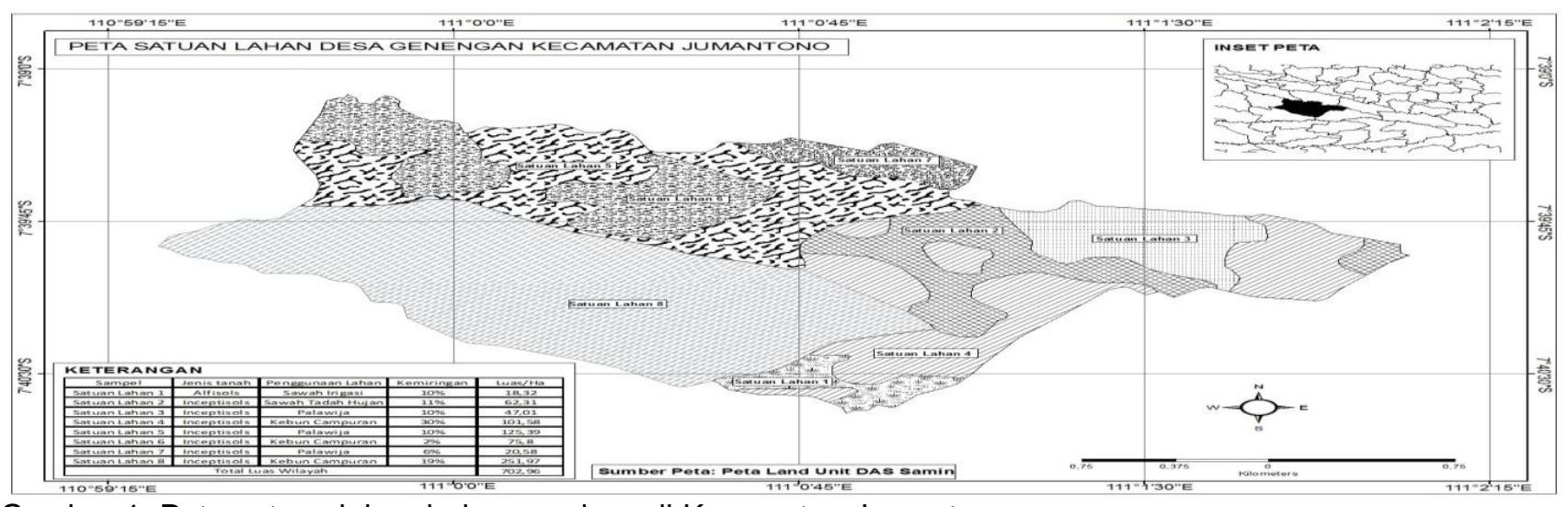

Gambar 1. Peta satuan lahan beberapa desa di Kecamatan Jumantono

Tabel 1. Nilai prediksi erosi $(A)$ dengan berbagai nilai erosivitas $(R)$

\begin{tabular}{|c|c|c|c|c|c|c|c|c|c|}
\hline \multirow[b]{2}{*}{ Sampel } & \multicolumn{3}{|c|}{ Erosivitas (R) } & \multirow[b]{2}{*}{$\mathrm{K}$} & \multirow[b]{2}{*}{ LS } & \multirow[b]{2}{*}{$\mathrm{CP}$} & \multicolumn{3}{|c|}{ Prediksi Erosi $(\mathrm{A})$} \\
\hline & $\begin{array}{l}\text { Lenvain } \\
1975\end{array}$ & $\begin{array}{l}\text { Lenvain } \\
1989\end{array}$ & Bols & & & & $\begin{array}{l}\text { Lenvain } \\
1975\end{array}$ & $\begin{array}{l}\text { Lenvain } \\
1989\end{array}$ & Bols \\
\hline Satuan lahan 1 & 13882,44 & 1628,05 & 2143,63 & 0,16 & 0,95 & 0,01 & 21,32 & 2,50 & 3,29 \\
\hline Satuan lahan 2 & 13882,44 & 1628,05 & 2143,63 & 0,09 & 1,52 & 0,01 & 18,92 & 2,22 & 2,92 \\
\hline Satuan lahan 3 & 13882,44 & 1628,05 & 2143,63 & 0,18 & 1,26 & 0,14 & 448,02 & 52,54 & 69,18 \\
\hline Satuan lahan 4 & 13882,44 & 1628,05 & 2143,63 & 0,22 & 2,52 & 0,08 & 467,36 & 54,81 & 72,17 \\
\hline Satuan lahan 5 & 13882,44 & 1628,05 & 2143,63 & 0,06 & 1,23 & 0,15 & 149,34 & 17,51 & 23,06 \\
\hline Satuan lahan 6 & 13882,44 & 1628,05 & 2143,63 & 0,26 & 0,68 & 0,10 & 247,52 & 29,03 & 38,22 \\
\hline Satuan lahan 7 & 13882,44 & 1628,05 & 2143,63 & 0,12 & 1,21 & 0,19 & 386,23 & 45,29 & 59,64 \\
\hline Satuan lahan 8 & 13882,44 & 1628,05 & 2143,63 & 0,12 & 2,07 & 0,07 & 241,20 & 28,29 & 37,24 \\
\hline
\end{tabular}


Berdasarkan Tabel 1, maka didapatkan berbagai hasil prediksi erosi metode USLE melalui berbagai pendekatan. Hasil prediksi erosi dengan metode pendekatan Erosivitas Lenvain 1989 menunjukkan pada satuan lahan 1 erosi yang terjadi adalah 2,50 ton/ha/th, pada satuan lahan 2 erosi yang terjadi adalah 2,22 ton/ha/th, pada satuan lahan 3 erosi yang terjadi adalah 52,54 ton/ha/th, pada satuan Iahan 4 erosi yang terjadi adalah 54,81 ton/ha/th, pada satuan lahan 5 erosi yang terjadi adalah 17,51 ton/ha/th, pada satuan lahan 6 erosi yang terjadi adalah 29,03 ton/ha/th, pada satuan lahan 7 erosi yang terjadi adalah 45,29 ton/ha/th dan pada satuan lahan 8 erosi yang terjadi adalah 28,29 ton/ha/th.

Hasil prediksi erosi dengan metode pendekatan Erosivitas Lenvain 1975 menunjukkan pada satuan lahan 1 erosi yang terjadi adalah 21,32 ton/ha/th, pada satuan lahan 2 erosi yang terjadi adalah 18,92 ton/ha/th, pada satuan lahan 3 erosi yang terjadi adalah 448,02 ton/ha/th, pada satuan lahan 4 erosi yang terjadi adalah 467,36 ton/ha/th, pada satuan lahan 5 erosi yang terjadi adalah 149,34 ton/ha/th, pada satuan lahan 6 erosi yang terjadi adalah 247,52 ton/ha/th, pada satuan lahan 7 erosi yang terjadi adalah 386,23 ton/ha/th dan pada satuan lahan 8 erosi yang terjadi adalah 241,20 ton/ha/th.

Hasil prediksi erosi dengan metode pendekatan Erosivitas Bols menunjukkan pada satuan lahan 1 erosi yang terjadi adalah 3,29 ton/ha/th, pada satuan lahan 2 erosi yang terjadi adalah 2,92 ton/ha/th, pada satuan lahan 3 erosi yang terjadi adalah 69,18 ton/ha/th, pada satuan lahan 4 erosi yang terjadi adalah 72,17 ton/ha/th, pada satuan Iahan 5 erosi yang terjadi adalah 23,06 ton/ha/th, pada satuan lahan 6 erosi yang terjadi adalah 38,22 ton/ha/th, pada satuan lahan 7 erosi yang terjadi adalah 59,64 ton/ha/th dan pada satuan lahan 8 erosi yang terjadi adalah 37,24 ton/ha/th.

Berdasarkan hasil perhitungan prediksi erosi metode USLE dengan berbagai pendekatan diatas, maka pendekatan Bols akan digunakan sebagai acuan menghitung erosivitas pada penelitian ini. Hal ini karena perolehan rumus erosivitas Bols didapatkan dengan mengumpulkan data curah hujan bulanan di 47 stasiun penakar hujan selama 38 tahun di Pulau Jawa (Asdak 2007), jadi bisa dikatakan metode pendekatan Bols sudah lazim dipakai untuk menghitung nilai erosivitas terutama di Pulau Jawa. Adanya data pendukung curah hujan harian dan bulanan di daerah penelitian juga menjadi faktor utama penggunaan rumus pendekatan Bols sebagai acuan untuk penghitungan nilai erosivitas.

\section{Nilai Erosi yang dapat Ditoleransikan (Etol) pada Satuan di Desa Genengan Kecamatan Jumantono Beserta Rekomendasi Teknologi Konservasi}

Penetapan nilai Etol dimaksudkan untuk mengetahui apakah sistem usaha tani yang diterapkan berkelanjutan ata tidak. Jika nilai prediksi erosi < Etol, maka system usaha tani berkelanjutan. Sebaliknya jika nilai prediksi Erosi > Etol, maka system usaha tani yang diterapkan sudah tidak berkelanjutan melainkan pada lahan tersebut suatu saat tidak produktif lagi dan akan menjadi lahan kritis. Untuk itu perlu dilakukan perubahan agroteknologi dalam system usaha tani dan atau alternatif sistem pertanian lain (Suyana 2012). Nilai erosi yang masih dapat ditoleransikan (Etol) pada tiap satuan lahan di kecamatan jumantono akan disajikan Gambar 2.

Dari hasil analisis data dengan menggunakan metode Wood dan Dent (1983) pada tiap satuan lahan Desa Genengan, maka dapat diketahui bahwa satuan lahan 1, 2, 5, 6 dan 8 nilai toleransi masih lebih kecil dari Etol sehingga masih bisa dikatakan sistem usahatani pada satuan lahan tersebut masih berkelanjutan. Untuk satuan lahan 3, 4 dan 7 nilai erosi masih lebih besar dari nilai Etol sehingga usahatani pada lahan tersebut memerlukan tindakan konservasi yang sesuai dan memadai untuk menurunkan erosi pada daerah tersebut.

Berbagai usaha dapat dilakukan untuk menurunkan nilai erosi, salah satunya adalah penggunaan mulsa jerami. Hasil penelitian dari Sinukaban (2007) menyatakan bahwa besarnya penurunan erosi akibat peningkatan penutupan mulsa jerami sebanyak $30 \%, 60 \%$ dan $90 \%$ adalah berturut turut sebanyak $21 \%, 62 \%$ dan $66 \%$. Fungsi mulsa jerami tersebut adalah mampu melindungi tanah dari timbunan energi hujan yang jatuh sehingga sedikit butiran tanah yang terdispersi dan tersedia untuk terbawa aliran air. Hasil penelitian dari Triwilaida (2001 cit. BTPDAS 2007) pemberian bahan organik dalam bentuk kompos sebanyak 40 ton/ha mampu meningkatkan indeks stabilitas agregat dari 62,73 menjadi 290,79 atau dengan kata lain menurunkan indeks erodibilitas (K) sekitar $30 \%$. Usaha lain adalah dengan menanam tanaman penutup tanah dengan pola strip pada tanaman utama. Sinukaban (2007) menyatakan bahwa efektivitas strip rumput vetiver atau akar wangi dalam mengurangi erosi dan aliran permukaan terlihat pada musim tanam kedua. Pada perlakuan lebar strip 3, 6 dan 9 baris tanaman dapat menekan aliran permukaan berturut - turut sebesar $30,5 \%, 29,8 \%$ dan $35,7 \%$ dan menurunkan erosi sebesar $51,5 \%, 35,4 \%$ dan $42,3 \%$ dibanding tanpa strip akar wangi. Dengan adanya berbagai hasil penelitian mengenai berbagai tindakan atau upaya konservasi untuk menurunkan laju erosi. Maka rekomendasi teknologi konservasi untuk menurunkan laju erosi yang melewati batas toleransi pada sistem pertanian didesa genengan akan disajikan pada tabel 2. 


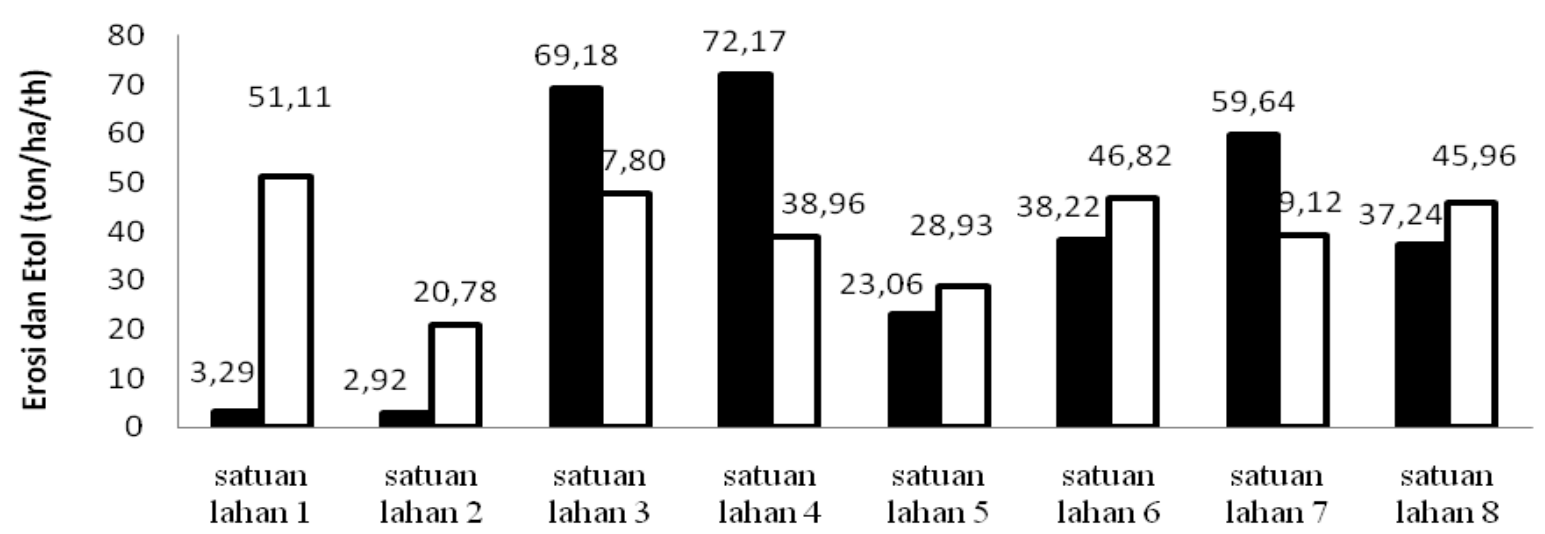

Gambar 2. Histogram prediksi erosi dan etol satuan lahan beberapa desa di Kecamatan Jumantono

Pada satuan lahan 3 rekomendasi yang bisa dilakukan untuk menurunkan erosi dibawah nilai Etol sebesar 47,80 ton/ha/th adalah menanam strip 9 baris akar wangi disela-sela tanaman utama pada daerah tersebut yaitu yang akan menurunkan erosi sebesar $42,3 \%$ sehingga erosi menjadi 39,92 ton/ha/th. Penggunaan mulsa jerami penutupan $60 \%$ yang akan menurunkan erosi sebesar $62 \%$ sehingga erosi menjadi sebesar 26,29 ton/ha/th. Aplikasi bahan organik kompos 40 ton/ha serta memperbaiki konstruksi teras bangku dari teras kurang baik menjadi konstruksi sedang yang akan menurunkan erosi menjadi sekitar 21,07 ton/ha/th.

Pada satuan lahan 7 , rekomendasi usaha yang bisa dilakukan untuk menurunkan erosi dibawah nilai Etol sebesar 39,12 ton/ha/th adalah aplikasi bahan organik kompos 40 ton/ha akan menurunkan erosi menjadi sebesar 39,06 ton/ha/th. Usaha lain adalah penggunaan strip 9 baris akar wangi yang mampu menurunkan erosi sebesar $42,3 \%$ sehingga besarnya erosi akan menjadi 37,12 ton/ha/th. Upaya penggunaan mulsa jerami tutupan $60 \%$ juga disarankan pada satuan lahan 7 yang dapat menurunkan erosi $62 \%$ sehingga menjadi sebesar 22,67 ton/ha/th.

Pada satuan lahan 4 dengan erosi sebesar 72,17 ton/ha/th dengan Etol hanya 38,96 ton/ha/th upaya yang dapat dilakukan adalah aplikasi bahan organik kompos 40 ton/ha ditambah penggunaan mulsa jerami tutupan $30 \%$ akan menurunkan erosi menjadi sebesar 38,80 ton/ha/th. Upaya lain adalah aplikasi strip 3 baris akar wangi dan penggunaan mulsa jerami tutupan $60 \%$ akan menurunkan masing-masing erosi menjadi 35,00 ton/ha/th dan 27,83 ton/ha/th.

Tabel 2. Alternatif teknologi konservasi untuk menurunkan laju erosi pada beberapa satuan lahan di Kecamatan Jumantono

\begin{tabular}{|c|c|c|c|c|c|c|c|}
\hline Sampel & Kondisi Lapang & Alternatif Konservasi & $\mathrm{K}$ & LS & $\mathrm{CP}$ & $\begin{array}{c}\text { A } \\
(\text { ton ha-1) }\end{array}$ & $\begin{array}{c}\text { Etol } \\
\text { (ton ha-1) }\end{array}$ \\
\hline \multirow{4}{*}{$\begin{array}{l}\text { Satuan } \\
\text { lahan } 3\end{array}$} & Kemiringan $10 \%$ & & 0,18 & 1,26 & 0,14 & 69,18 & 47,80 \\
\hline & & - Strip 9 baris akar wangi & - & - & - & 39,92 & \\
\hline & & - Mulsa jerami $60 \%$ & - & . & - & 26,29 & \\
\hline & & $\begin{array}{l}\text { - Aplikasi bahan organik } \\
\text { kompos } 40 \text { ton/ha + } \\
\text { Teras bangku konstruksi } \\
\text { sedang }\end{array}$ & 0,13 & 1,26 & 0,06 & 21,07 & \\
\hline \multirow{4}{*}{$\begin{array}{l}\text { Satuan } \\
\text { lahan } 4\end{array}$} & Kemiringan $22 \%$ & & 0,22 & 2,52 & 0,08 & 72,17 & 38,96 \\
\hline & & $\begin{array}{l}\text { - Aplikasi bahan organik } \\
\text { kompos } 40 \text { ton/ha + Mulsa } \\
\text { jerami } 30 \%\end{array}$ & - & - & - & 38,80 & \\
\hline & & $\begin{array}{l}\text { - Aplikasi Strip } 3 \text { baris akar } \\
\text { wangi }\end{array}$ & - & - & - & 35,00 & \\
\hline & & - Mulsa jerami $60 \%$ & - & - & - & 27,83 & \\
\hline \multirow{4}{*}{$\begin{array}{l}\text { Satuan } \\
\text { lahan } 7\end{array}$} & Kemiringan 6\% & & 0,12 & 1,21 & 0,19 & 59,64 & 39,12 \\
\hline & & $\begin{array}{l}\text { - Aplikasi bahan organik } \\
\text { kompos } 40 \text { ton/ha }\end{array}$ & 0,08 & 1,21 & 0,19 & 39,06 & \\
\hline & & - Strip 9 baris akar wangi & - & - & - & 37,12 & \\
\hline & & - Mulsa jerami $60 \%$ & - & . & - & 22,67 & \\
\hline
\end{tabular}

Metode USLE untuk Memprediksi Erosi Tanah dan Nilai Toleransi

Ari Widodo, Komariah, Jaka Suyana 


\section{KESIMPULAN DAN SARAN}

\section{Kesimpulan}

Besarnya nilai Erosivitas di daerah Jumantono dengan pendekatan Asdak adalah 1628,05 dengan prediksi erosi $(2,22-72,04)$ ton/ha/th, Lenvain adalah 13882,44 dengan prediksi erosi $(18,92-614,28)$ ton/ha/th dan Bols adalah 2143,63 dengan prediksi erosi $(2,92-94,85)$ ton/ha/th. Untuk satuan lahan 3, 4 dan 7 besarnya nilai prediksi erosi sudah melebihi nilai toleransi yang artinya memerlukan tindakan konservasi. Arahan tindakan konservasi yang direkomendasikan pada satuan lahan 3 dengan menanam strip 9 baris akar wangi disela tanaman utama. Pada satuan lahan 4 dan satuan lahan 7 upaya yang disarankan adalah aplikasi mulsa jerami tutupan $60 \%$.

\section{Saran}

Hampir 30\% dari 703, 06 Ha lahan pertanian di beberapa Desa di Kecamatan Jumantono tidak berkelanjutan, maka usaha konservasi yang disarankan diatas perlu diupayakan untuk mengurangi resiko degradasi lahan dan dalam mewujudkannya perlu adanya kerjasama yang baik dari petani maupun pemerintah daerah.

\section{DAFTAR PUSTAKA}

Abas A, Abdurrachman A. 1985. Pengaruh pengelolaan air dan pengelolaan tanah terhadap efisiensi penggunaan air padi sawah di Cihea, Jawa Barat. Pemb. Penelitian Tanah dan Pupuk, Bogor (ID): PPT 4: 1-4.

Arsyad S. 2000. Pengawetan tanah dan air. Bogor (ID): Institut Pertanian Bogor.

Arsyad S. 2006. Konservasi tanah dan air. Edisi kedua Cetakan pertama. Bogor (ID): Penerbit IPB Press.

Arsyad S. 2010. Konservasi tanah dan air. Edisi kedua Cetakan kedua. Bogor (ID): Penerbit IPB Press.

Asdak C. 2007. Hidrologi dan pengelolaan DAS. Yogyakarta (ID): Gajah Mada Univ. Press,

Banuwa SI. 2013. Erosi. Edisi pertama. Jakarta (ID): Kencana Prenada Media Grup.

BAPPEDA. 2012. Data kependudukan daerah kabupaten Karanganyar.

BTPDAS 2000. Pedoman konservasi tanah dan air. Pusat Balai Penelitian dan Teknik Pengelolaan Daerah Aliran Sungai. Surakarta.

Direktorat Jenderal Reboisasi dan Rehabilitasi Lahan. 1989. Petunjuk pelaksanaan rencana teknik lapangan dan rehabilitasi lahan dan konservasi tanah. Ditjen RRL. Departemen Kehutanan.

Fahmi MAN. 2012. Prediksi erosi dengan metode USLE pada penggunaan lahan hutan, semak dan pinus di Desa Tengklik dan Kalisoro. Skripsi Sarjana pada UNS Surakarta. tidak diterbitkan.
Hammer WI. 1978. Soil conservation consultant report. INS/78/006. Technical Note No. 7. Soil Research Institute, Bogor.

Hammer WI. 1981. Second soil conservation consultant report. AGOF/INS/78/006. Tech. Note No.10. Centre for Soil Research, Bogor (ID).

Hardjowigeno S. 2007. Ilmu tanah. Jakarta (ID): Penerbit Akademika Pressindo.

Hardjowigeno S, Sukmana S. 1995. Menentukan tingkat bahaya erosi. Centre for Soil and Agroclimate Research. Bogor. $42 \mathrm{Hal}$.

Kartasapoetra AG. 1989. Kerusakan tanah pertanian dan usaha untuk merehabilitasinya. Jakarta (ID): Bina Aksara.

Kartasapoetra AG. 2005. Teknologi konservasi tanah dan air. Cetakan kelima, maret 2005. Jakarta (ID): Penerbit PT Rineka Cipta.

Nearing MA, Lane LJ, Lopes VL. 1994. Modelling soil erosion. In: Lal, R. (Ed.). Soil Erosion Methods. Soil and Water Conservation Society. Florida (US): 127-158.

Raharjo PD, Saifudin. 2008. Pemetaan erosi DAS luk ulo dengan menggunakan data penginderaan jauh dan sistem informasi geogfrai. J IImu Tanah dan Lingkungan 8(2): 103-113.

Rahim SE. 1996. Pengendalian erosi tanah : Dalam rangka pelestarian lingkungan hidup. Ed.1, Cet. 3. Jakarta (ID): Bumi Aksara.

Sinukaban. 2007. Konservasi tanah dan air dalam pengendalian erosi dan rehabilitasi lahan. Pusat Penelitian dan Pengembangan Tanah dan Agroklimat. Bogor.

Subagyo H, Suharta N, Siswanto AB. 2000. Tanahtanah pertanian di Indonesia. hlm. 21-66. Dalam Abdurachman. (Ed.). Sumberdaya lahan Indonesia dan pengelolaannya. Pusat Penelitian dan Pengembangan Tanah dan Agroklimat, Bogor.

Suyana J. 2012. Pengembangan usaha tani lahan kering berkelanjutan berbasis tembakau di sub-das progo hulu (Kabupaten Temanggung Propinsi Jawa Tengah). Disertasi Doktor pada IPB Bogor: tidak diterbitkan.

Syarif S. 1985. Konservasi tanah dan air. Bandung (ID): Penerbit Pustaka Buana.

Triyono K. 2007. Pengaruh sistem pengolahan tanah dan mulsa terhadap konservasi sumber daya tanah. J Inov Pert 6(1): 11-21.

Wischmeier WH, Smith DD. 1978. Predicting rainfall erosion losses a guide to conservation planning. USDA Agric. Handb (537): 58.

Wood SR, Dent FJ. 1983. LECS. A land evaluation computer system methodology. Center for Soil Research, Bogor - AARD. AGOF/INS/7 8/006. Manual 5 Version 1.

Wudianto R. 2001. Mencegah erosi. Bandung (ID): Penerbit Pustaka Buana. 